\title{
A instável verdade nos testemunhos sobre estupros na seção 'Eu, leitora' da revista Marie Claire
}

\author{
The unstable truth in the testimonies about rapes in the 'Eu, leitora' \\ section of Marie Claire magazine
}

\section{La inestable verdad en los testimonios sobre violaciones en la sección de 'Eu, leitora' de la revista Marie Claire}

\author{
Karina Gomes Barbosa ${ }^{1, a}$ \\ karina.barbosa@gmail.com | https://orcid.org/o000-0002-1860-3622
}

\section{Rafiza Varão, ${ }^{2, a}$}

rafiza@gmail.com | https://orcid.org/o0oo-0003-0383-5524

${ }^{1}$ Universidade Federal de Ouro Preto, Instituto de Ciências Sociais Aplicadas, Departamento de Jornalismo. Mariana, MG, Brasil.

2 Universidade de Brasília, Faculdade de Comunicação, Departamento de Jornalismo. Brasília, DF, Brasil.

a Doutorado em Comunicação Social pela Universidade de Brasília.

\section{RESUMO}

Neste artigo, investigamos os modos como o jornalismo enquadra narrativas testemunhais de estupro publicadas na última década na seção 'Eu, leitora' da revista Marie Claire brasileira. A partir de uma análise textual narrativa, cotejada com estudos de trauma e testemunho e com estudos feministas, buscamos problematizar a maneira como o jornalismo lida com o testemunho. Dialogamos com o conceito de fait divers e sua presença no jornalismo dito feminino para compreender os modos como Marie Claire enquadra esses relatos. Concluímos que a revista opera ambiguamente em relação à verdade testemunhal das feridas traumáticas dessas mulheres, ao mesmo tempo se aproximando e se afastando delas, por meio de estratégias narrativas e editoriais.

Palavras-chave: Estupro; Testemunho; Jornalismo; Estudos de gênero; Marie Claire.

\section{ABSTRACT}

In this article, we investigate how the journalism frames narratives of testimonies about rapes published in the last decade in the 'Eu, leitora' section of the Brazilian Marie Claire magazine. By means of a narrative textual analysis, compared with testimony and trauma studies as well as feminist studies, we seek to problematize the way journalism deals with testimony. We dialogue with the concept of fait divers and its presence in so-called female journalism to understand how Marie Claire frames these reports. We conclude that the magazine operates ambiguously with regard to the testimony truth of the traumatic wounds of these women, at the same time approaching and moving away from them, through narrative and editorial strategies.

Keywords: Rape; Testimony; Journalism; Gender studies; Marie Claire. 


\section{RESUMEN}

En este artículo investigamos cómo el periodismo encuadra las narrativas testimoniales de violación publicadas en la última década en la sección de 'Eu, leitora' de la revista brasileña Marie Claire. A partir de un análisis textual narrativa, comparado con estudios del trauma y del testimonio y con estudios feministas, buscamos problematizar la forma cómo el periodismo aborda el testimonio. Dialogamos con el concepto de fait divers y su presencia en el llamado periodismo femenino para entender las formas cómo Marie Claire enmarca esas narraciones. Concluimos que la revista opera de manera ambigua con relación a la verdad testimonial de las heridas traumáticas de esas mujeres, al mismo tiempo acercándose y alejándose de ellas, a través de estrategias narrativas y editoriales.

Palabras clave: Violación; Testimonio; Periodismo; Estudios de género; Marie Claire.

Contribuição dos autores:

Concepção e desenho do estudo: Karina Gomes Barbosa e Rafiza Varão.

Aquisição, análise ou interpretação dos dados: Karina Gomes Barbosa e Rafiza Varão.

Redação do manuscrito: Karina Gomes Barbosa e Rafiza Varão.

Revisão crítica do conteúdo intelectual: Karina Gomes Barbosa e Rafiza Varão.

Declaração de conflito de interesses: não há.

Fontes de financiamento: não houve.

Considerações éticas: não há.

Agradecimentos/Contribuições adicionais: não há.

Histórico do artigo: submetido: 02 mar. 2021 | aceito: 14 jul. 2021 | publicado: 31 ago. 2021.

Apresentação anterior: não há.

Licença CC BY-NC atribuição não comercial. Com essa licença é permitido acessar, baixar (download), copiar, imprimir, compartilhar, reutilizar e distribuir os artigos, desde que para uso não comercial e com a citação da fonte, conferindo os devidos créditos de autoria e menção à Reciis. Nesses casos, nenhuma permissão é necessária por parte dos autores ou dos editores. 


\section{INTRODUÇÃO}

A revista Marie Claire, publicação francesa nascida em 1937, chegou ao Brasil em 1991, pelas mãos da editora Globo. De acordo com Mônica Serino (2008), junto com a primeira edição, veio a seção 'Eu, leitora’’ Serino, que foi diretora de redação da revista, conta que "a seção foi pioneira ao introduzir esse espaço onde as leitoras contam um episódio de sua vida em primeira pessoa" (2008, p. 7). Na descrição de Danieli Aparecida Campos (2013, p. 103), a seção se caracteriza “[...] essencialmente pelo gênero depoimento, apresentando uma única voz, desde o título, que já vem aspeado, até todo o texto corrido. A voz do narrador aparece apenas no olho da matéria, onde faz a apresentação da personagem, que, além de leitora, aqui se transforma em autora”. Nossa observação amplia esse panorama: a figura do/a narrador/a de 'Eu, leitora' surge, também, eventualmente em títulos na terceira pessoa e em outras marcas textuais como dedosduros, mas o relato é fundamentalmente em primeira pessoa. Olhos, títulos, linhas finas e dedos-duros, elementos paratextuais, revelam uma segunda voz no testemunho: a presença mediadora do/a jornalista, como narrador/a, nesses textos.

'Eu, leitora' constitui um sucesso editorial, presente em edições internacionais de Marie Claire. Em 2008, ganhou um livro no Brasil, O melhor do Eu, leitora, com 28 depoimentos que Rosane Queiroz (2008) considera os mais marcantes entre os mais de 200 até então publicados. São narrativas em primeira pessoa, mediadas por uma jornalista (que emula a primeira voz da mulher-narradora), de dramas pessoais, superações, sucessos. “[...] Surpreendentes, incrivelmente sinceros, quase sempre inacreditáveis”, define Queiroz (2008, p. 9). Tão incríveis que beiram o inacreditável, conta a jornalista, que editou a seção por quatro anos: "Basta passar uma tarde lendo as confissões das leitoras para ver como a realidade pode ser, mesmo, mais estranha que a ficção" (2008, p. 10).

Ao associar as narrativas de 'Eu, leitora' com as cartas recebidas pela redação, Suelly Maria Maux Dias informa que as histórias recebidas para publicação na seção precisam ser verídicas e as autoras (ou autores) podem ter nome e imagem omitidos.

São Cartas, enviadas, por homens e mulheres, de todas as idades e classes sociais, contando uma história de sua vida. Após a escolha da Carta, a ser publicada, uma repórter é designada a entrar em contato com a pessoa e conjuntamente reconstruir seu texto. No editorial de abril de 1993, a editora Regina Lemos informa que a seção 'Eu, leitora' tem $46,46 \%$ das preferências das leitoras e que a redação recebe em média umas 400 cartas mensais. (DIAS, 2003, p. 8-9)

Os temas publicados por 'Eu, leitora' ficam explícitos já nos títulos, como 'Deixei meu marido por um peão de fazenda', 'O impossível aconteceu: peguei o diploma', 'Uma gata mudou minha vida'. Dias (2003) classifica as temáticas da seção em seis, a saber: família, paixão, casamento, filhos, corpo e relacionamentos/ conquistas com diferenças de idade. A autora também aproxima as narrativas de 'Eu, leitora' ao folhetim:

[...] são publicados ora de forma folhetinesca, ora sob o prisma de manuais de 'bom comportamento', como muitas revistas femininas fazem hoje em relação à moda, ao estilo, ao comportamento, ao padrão de beleza feminina e masculina, e principalmente à forma de conduzir o cotidiano que enformam e engessam a mulher. (DIAS, 2003, p. 11)

Há também em 'Eu, leitora' uma proximidade com os fait divers, que Morin define como "aquela 'franja do real em que o inesperado, o bizarro, o assassínio, o incidente, a aventura, irrompem na vida quotidiana" (MORIN apud WOLF, 2002, p. 103), e que beiram o espantoso, o sensacional, o inacreditável e, também, o admirável (VIEGAS, 2014) - associados aos relatos que não se enquadram nas editorias tradicionais e

1 A seção francesa equivalente, ainda em circulação, é intitulada 'Moi lectrice'. Segundo Dias (2003), até 1998 a seção era publicada sob a rubrica de reportagem. 
parecem mesmo irreais, por terem conteúdo próximo da ficção. Durante a pandemia de covid-19, muitos relatos publicados na seção se relacionam ao novo coronavírus, como 'Peguei Covid-19 sem nunca ter saído de casa'; 'Peguei coronavírus com 5 colegas e só eu, com 86 anos, e mais um voltamos para casa'; 'Dia das Namoradas: ‘A quarentena foi o empurrão que faltava no nosso relacionamento”, entre outros. Esse movimento ainda contempla a ideia de um espaço para o entretenimento, que oscila, por vezes, entre a narrativa fantástica e o 'fato’ jornalístico. A estratégia é frequente na revista e já havia sido utilizada diante de acontecimentos midiáticos como as enchentes do Espírito Santo, em 2020.

Ao mesmo tempo dentro e além dessas narrativas com gancho na atualidade e/ou de um mundo descrito como incrivelmente real (SERINO, 2008) que resvalam no pitoresco, no curioso, a seção 'Eu, leitora' apresenta um conjunto de experiências narradas em primeira pessoa de um outro universo, mas nem por isso menos familiar às mulheres: o da violência sexual. Na última década, mulheres (em sua imensa maioria, embora Dias enumere a presença de alguns relatos de homens no espaço editorial) recorrem à revista (ou são convidadas pela publicação) para dar testemunho de experiências traumáticas que sofreram, notadamente estupros. Um conjunto substancial dessas narrativas de si adveio dessa estratégia discursiva da revista de acionar acontecimentos que circulam socialmente, a partir de uma campanha feita pela Marie Claire em 2016, após o estupro coletivo sofrido por uma adolescente de 16 anos na Zona Oeste do Rio de Janeiro, cujas imagens circularam nas redes sociais, e que gerou intensa comoção². Após o evento, a publicação pediu para mulheres enviarem relatos, que poderiam ser anônimos, narrando suas experiências: "Marie Claire acredita que falar sobre o problema é a melhor forma de combatê-lo e por isso, decidimos publicar um relato de violência sexual por dia, durante 33 dias. Se a matemática da covardia era de 33 homens contra 1 mulher, a da coragem será de 33 mulheres contra toda a cultura do estupro" (REDAÇÃO MARIE CLAIRE, 2016).

Em sua convocação, a revista menciona a cultura do estupro, que entre outros mitos patriarcais perpetua a culpabilização da vítima. A partir desse contexto, nosso interesse é investigar os modos como o jornalismo enquadra essas narrativas testemunhais na seção de Marie Claire. E, partindo daí, buscamos problematizar a maneira como o jornalismo lida com o testemunho, realizando uma análise textual qualitativa com inspiração nos estudos da narrativa (MOTTA, 2013) de 13 relatos publicados na revista entre 2005 e 2019, cotejando-os com estudos de testemunho e de trauma (DAS, 2020; SELIGMANN-SILVA, 2008) e com estudos feministas (DESPENTES, 2018; SAFFIOTI, 2004; GAY, 2018; GOMES BARBOSA; VARÃO, 2018). Analisar os modos pelos quais o jornalismo aborda e enquadra, editorial e narrativamente, violências contra mulheres por meio de testemunhos de sobreviventes é relevante por apontar a complexidade de tentar engendrar mudanças sociais e promover rupturas em relação à ordem de gênero dominante que estrutura os discursos jornalísticos e dispõe dos corpos das mulheres como territórios de posse masculina (SEGATO, 2005). Desse modo, o texto auxilia a compreensão do jornalismo não só como prática textual, mas como elemento da própria cultura, como definiu Otto Groth (2011), e aponta ainda as dificuldades e avanços possíveis das lutas feministas.

Compreendemos as narrativas como possibilidades de "inteligibilidade da experiência social a partir de uma mise en intrigue" (ANTUNES, 2008, p. 2). Elton Antunes ressalta o caráter composicional da narrativa, ao produzir um relato "que representa o acontecimento jornalístico em uma dada configuração temporal que agencia ação e interpretação" (2008, p. 2). Nas narrativas testemunhais de acontecimentos traumáticos, como o estupro, tem-se uma aporia, dada a impossibilidade de narração da situação-limite (SELIGMANNSILVA, 2008) aliada à premência testemunhal. Nosso gesto, portanto, busca a compreensão desses relatos

2 Em uma matéria da Agência Lupa (BUSTAMANTE, 2017) há uma discussão mais aprofundada no caso, bem como alguns de seus desdobramentos. 
testemunhais como acontecimentos jornalísticos 3 , levando em conta a dificuldade dessa empreitada: para Motta (2013), a análise da narrativa jornalística parte da desordenação do tempo para reorganizá-lo de maneira coerente; ora, como discutimos adiante, a fragmentação e falta de linearidade temporal são características do testemunho, e a análise deve buscar, a nosso ver, os modos de sua configuração. Nos textos, damos especial atenção aos dêiticos temporais que os demarcam; às marcas de autoria expressas; às vozes presentes; e à configuração geral da temporalidade. Dialogamos com o conceito de fait divers e sua presença no jornalismo dito feminino para compreender os modos como Marie Claire enquadra esses relatos, tanto narrativamente quanto editorialmente.

\section{ESTUPRO, TRAUMA, TESTEMUNHOS DE ESTUPROS}

O Instituto Patrícia Galvão, no Dossiê Violência Contra as Mulheres, define violência sexual como qualquer "prática de cunho sexual que "não tenha sido consentida”" (INSTITUTO PATRÍCIA GALVÃO, 2015, grifo original). A questão do consentimento é fulcral na definição legal do crime de estupro, ao destacar o constrangimento para a prática de atos libidinosos ou conjunção carnal ${ }^{4}$. O dossiê ressalta as nuanças do consentimento: mulheres e meninas sem condição de consentir com práticas sexuais, como efeito de medicação ou álcool, também são vítimas de estupro. A publicação descreve ainda alguns modos pelos quais o estupro ocorre na prática, desmistificando imaginários prevalentes, como o que equipara estupro à penetração: “Tocar as partes íntimas de alguém sem consentimento, obrigar que alguém toque suas partes íntimas ou manter relações sexuais pela imposição de força, ameaça ou coerção" (INSTITUTO PATRÍCIA GALVÃO, 2015).

Da perspectiva feminista, as palavras-chave na definição do estupro são poder e controle. Busca-se, no estupro, retirar à força o poder do outro sobre si mesmo, tentando usurpá-lo por meio da subjugação sexual. No contexto do heteropatriarcado ${ }^{5}$ nomeado por Françoise Vergès (2020), Rita Laura Segato (2005) afirma que o estupro conjuga os domínios físico e moral sobre o outro. O corpo da mulher é visto como território, a ser ocupado, desumanizado e disposto para um "canibalismo mediante o qual o outro perece como vontade autônoma, e sua oportunidade de existir somente persiste se é apropriada e incluída no corpo de quem o devorou. O resto de sua existência persiste somente como parte do projeto do dominador" (2005, p. 270). O canibalismo/estupro operado no heteropatriarcado dirige-se ao "aniquilamento da vontade da vítima, cuja redução é justamente significada pela perda do controle sobre o comportamento de seu corpo e o agenciamento do mesmo pela vontade do agressor", continua Segato (p. 270).

Ao analisar a reiteração de representações midiáticas audiovisuais sobre estupro, Gomes Barbosa (2020) afirma que "sob o patriarcado, o estupro é uma experiência traumática que integra a construção do gênero feminino; e, nesse sentido, ser estuprada, ou estar sujeita ao estupro, faz parte do que é viver como mulher" (p. 10). Os números indicam que se trata, de fato, de uma violência estrutural que, apesar de poder ser direcionada aos homens, atinge majoritariamente as mulheres: dados da $14^{\mathrm{a}}$ edição do Anuário

3 Para Motta (2013, p. 104), o cotidiano passa a ser vivido sob o signo do acontecimento e de seus ecos - a cobertura jornalística. Neste sentido, podemos compreender o conjunto de narrativas analisadas aqui como parte de uma cobertura mais ampla de Marie Claire sobre o estupro no Brasil.

4 Desde 2009, a legislação brasileira ampliou a definição de estupro, deixando de considerar a conjunção carnal como marcador único desse tipo de violência sexual, além de incluir outros atos libidinosos, acolher a possibilidade de estupro contra homens e tipificar o estupro de vulnerável. Segundo Samira Bueno e Isabela Sobral (2020, p. 133), a legislação "inovou ao reconhecer a dignidade sexual como direito de todas as pessoas, independentemente do gênero, além de retirar a violência sexual da esfera dos costumes, colocando a dignidade sexual como direito a ser protegido".

5 Para Vergès, um patriarcado "neofascista e masculinista", que ataca mulheres e a comunidade LGBTQI+. Nesse sistema, "só é aceitável a submissão das mulheres à sua ordem heteronormativa", instituída por medidas como iniciações ao estupro ou assassinatos de feministas. Diz Vergès: “[...] o patriarcado neofascista não hesita em lançar mão da tortura, do desaparecimento, da prisão e da morte contra as mulheres" (VERGÈS, 2020, p. 119-120). Os estupros seriam, assim, crimes cometidos no contexto do heteropatriarcado como um instrumento de poder sobre os corpos femininos. 
Brasileiro de Segurança Pública (BUENO; SOBRAL, 2020) apontam que ocorre um estupro no país a cada 8 minutos, sendo $85,7 \%$ das vítimas mulheres. Em sua magnitude perversa, os dados ainda escondem uma subnotificação: segundo o anuário, o número pode ser até duas vezes maior (BUENO; SOBRAL, 2020).

O estupro é um tipo de violência prevalentemente cometido contra corpos femininos (SAFFIOTI, 2004), decorrente de uma "organização social de gênero, que privilegia o masculino" (SAFFIOTI, 2004, p. 85). São violências de caráter traumático, "feridas na alma" (p. 19) que precisam ser curadas (SAFFIOTI, 2004). O estupro constitui uma experiência traumática, e, pela natureza, interdita o acesso do sujeito à linguagem e retira-o do fluxo linear da vida e do tempo, prendendo-o a um presente/passado que nunca cessa (SELIGMANN-SILVA, 2008). A possibilidade de saída do trauma, a reparação do sujeito cindido, passa pelo testemunho, ainda que diferentes modalidades de testemunho possam responder a distintas feridas traumáticas, de acordo com Veena Das (2020). Para nós, o testemunho funda-se na violência: traumática, fragmenta a temporalidade do sujeito sobre quem essa dor foi infligida. Para reintegrar-se ao fluxo temporal da vida (e de si), o sujeito busca narrar, contar, reordenar as violências sofridas, uma necessidade ao mesmo tempo premente e quase inalcançável, pois como representar o limite da vida? (SELIGMANN-SILVA, 2008). O testemunho é, também, uma potente narrativa contra o esquecimento e o apagamento de violências sofridas, sobretudo por corpos subalternos, às margens das relações de poder. Permite a afirmação de verdades subjetivas e coletivas que, de outro modo, seriam escamoteadas (memórias subterrâneas) por memórias oficiais e dominantes (POLLAK, 1989), como os genocídios cometidos contra os armênios e contra os tutsis ruandeses, ou as ditaduras latino-americanas. Logo, o testemunho é simultaneamente subjetivo e coletivo.

O conjunto de relatos testemunhais de estupros em ' $\mathrm{Eu}$, leitora' trata de relatos subjetivos, individuais, e também coletivos, ao darem conta da dimensão estrutural e sistêmica das violências contra as mulheres. Seus efeitos são subjetivos, ou seja, para cada mulher que conta sua verdade testemunhal da experiência traumática e quase indizível, e também sociais: impedem que a palavra 'estupro' continue proscrita, trazem à esfera pública 'essa' violência - e, com ela, seus perpetradores. Outra característica do testemunho é pressupor alguém que testemunha e um Outro, sujeito ativo de escuta, crença e partilha, com quem se cria uma comunidade afetiva: "Para poder relatar seus sofrimentos, uma pessoa precisa antes de mais nada encontrar uma escuta”, diz Pollak (1989, p. 6). Jornalistas que captam os relatos de 'Eu, leitora' atuam como as testemunhas que escutam e transportam a história:

[...] testemunha não seria somente aquele que viu com seus próprios olhos, o bistor de Heródoto, a testemunha direta. Testemunha também seria aquele que não vai embora, que consegue ouvir a narração insuportável do outro e que aceita que suas palavras levem adiante, como num revezamento, a história do outro: não por culpabilidade ou por compaixão, mas porque somente a transmissão simbólica, assumida apesar e por causa do sofrimento indizível, somente essa retomada reflexiva do passado pode nos ajudar a não repeti-lo infinitamente, mas a ousar esboçar uma outra história, a inventar o presente. (GAGNEBIN, 2006, p. 57, grifo original)

No livro Not that bad (2018), que reúne testemunhos diversos relacionados a violências sexuais e à cultura do estupro, Roxane Gay classifica esses relatos como histórias de pessoas dando voz ao sofrimento causado pela violência sexual, compartilhando experiências, demandando serem ouvidas. A própria ativista foi estuprada aos 12 anos e narrou sua história por acreditar no compartilhamento dessas experiências e que, ao fazer isso, "mais e mais pessoas possam se horrorizar com o sofrimento originado pela violência sexual e quão extensas podem ser as suas repercussões” (GAY, 2017, p. 40). Ela destaca que há mudanças recentes e que sobreviventes começam a falar, a denunciar (GAY, 2018). Essas mudanças se espraiam também pelo jornalismo dito feminino, como é o caso da Marie Claire e dos relatos de teor testemunhal que vêm sendo publicados em outros veículos sobre estupros nos anos recentes. Contudo, dito pelas vozes 
de suas sobreviventes (tradicionalmente desacreditadas), em lugares pouco privilegiados do ponto de vista das divisões editoriais do jornalismo, caminhando sobre a fronteira tênue de um relato que pode parecer menor e até mesmo adquirir vieses de fruição ficcional, o testemunho de 'Eu, leitora' ocupa posição ambígua. Campos (2013) assinala a presença da violência de gênero na revista, sobretudo em reportagens e perfis: em 10 anos, $40 \%$ das reportagens tinham "enfoque principal ou secundário na violência contra as mulheres” (p. 56). Porém, a autora também demarca a diferença narrativa da seção: “[...] ‘Eu, leitora’, da qual selecionamos duas, são cartas escritas (editadas pela revista) por mulheres” (2013, p. 52) ${ }^{6}$.

\section{SOBRE O JORNALISMO DITO FEMININO}

A edição brasileira de Marie Claire mantém o slogan 'Chique é ser inteligente'. A publicação, mensal, tem circulação atual de 75,8 mil exemplares, com cerca de 150 páginas por edição. Segundo dados do mídia kit da revista (MARIE CLAIRE, 2020), as mulheres constituem 89\% das leitoras da versão impressa e 56\% da digital. Na revista impressa, $66 \%$ de leitoras/es são da classe $\mathrm{AB}$ e, na internet, a porcentagem desse público é de 41\%. Marie Claire é a segunda revista do segmento Feminina/Comportamento/Beleza de maior circulação no país, atrás de Claudia, e a $15^{\mathrm{a}}$ em circulação digital, entre todos os segmentos (MÍDIA..., 2020). A estrutura editorial mescla assuntos como beleza, moda, compras, comportamento, cultura, gastronomia e "temas importantes para as mulheres" (MARIE CLAIRE, 2020), em formatos jornalísticos diversos, como artigos, reportagens, editoriais, ensaios, colunas, perfis. A organização editorial atual agrupa os conteúdos em: Na Capa; Tendências; Reportagem; Cultura; @Work; Colunas; Moda; Beleza; Lifestyle - além de Horóscopo e Tentação.

Dulcília Buitoni menciona que, desde o lançamento, Marie Claire se ancora em um público de alto poder aquisitivo, mulheres das classes A e B, e em marcas editoriais presentes na matriz francesa: "temas polêmicos, abordagens corajosas, longos depoimentos das leitoras, reportagens sobre diferentes culturas [...]" (2009, p. 160). A revista integra um contexto, dos anos 1990, de sofisticação do consumo que ampliou a segmentação, e de representações sobre as mulheres definidas por Buitoni como "a menina tem de se proteger na transa/a mulher sexy sabe sugerir o uso de camisinha" (2009, p. 201). Para Buitoni, o conteúdo novo é o sexo - e, notamos, não as lutas das mulheres ou pautas socialmente engajadas. Assim, a autora afirma que a imprensa feminina brasileira não mudou tanto ao longo do tempo: "Por mais que a liberdade seja alardeada, moda e beleza continuam a conformar. A mulher é estimulada a ser independente financeiramente, mas continua dependente do olhar masculino" (2009, p. 212).

Oquechamamos deimprensa feminina (eanteriormenteidentificamos comoo 'jornalismodito feminino'), categoria na qual Marie Claire é enquadrada, traz já em suas marcas arqueológicas a proximidade com os fait divers, embora não necessariamente recaia sobre o completamente inesperado ou inominável, mas nas beiradas do inútil, do pouco sério, do folhetinesco, do chocante passageiro, do que deve ser consumido pelas vias do entretenimento e menos sob o ângulo do notório interesse público.

Assim, se remontarmos à Revista Feminina (1914-1936), uma das primeiras grandes publicações voltadas para o público feminino no Brasil, o leque de pautas não se afasta daquilo que se esperava do universo feminino nem se aproxima dos temas das coberturas de referência. Estão ali o relacionamento homem/mulher, a casa, a maternidade, a busca da beleza - apesar de outros veículos similares fazerem investidas tímidas ou um pouco mais arriscadas rumo a um discurso feminista (DUARTE, 2017). Reflete-se, em veículos similares ou díspares, contemporâneos e posteriores, "a dicotomia vigente: ou se empenham

6 Do corpus da autora, composto de 27 textos jornalísticos, apenas dois são oriundos da seção 'Eu, leitora', outro indício da posição ambígua ou menor do testemunho na configuração editorial da revista. 
em acompanhar a transformação dos tempos; ou reiteram a fragilidade e a especificidade dos papéis sociais destinados à mulher" (DUARTE, 2017, p. 102).

Nessa especificidade, o comportamento alcança dimensão central (menos como editoria e mais no formato 'como se comportar'/'o que fazer'). Por isso, a moda se coloca como pertinente, a etiqueta, a culinária, os cuidados com a aparência, os relacionamentos. Passa-se a valorizar sobretudo a "entronização da 'divina missão' materna como 'guardiã privilegiada' da família. [...] Segundo tal 'mística', o melhor destino era 'viver a femilidade', ser 'recatada', ‘boa mãe' e 'esposa exemplar”' (DUARTE, 2017, p. 103). Há nessa circunscrição uma ideia de treinamento e, ao mesmo tempo, de observação do ideal do que seria ser mulher, numa espécie de jornalismo de notório interesse privado, de regulação do feminino que habitava os lares (noção que sofrerá pequenas modificações com a entrada maior das mulheres nos cenários públicos). Marie Claire promove, assim, um movimento duplo de aproximação e afastamento do jornalismo dito feminino, ao abordar assuntos como violências contra a mulher e hierarquias de gênero entre suas pautas7 .

Quando a figura do feminino se afastava daquelas dimensões, envolvendo, por exemplo, o assassínio listado por Morin (apud WOLF, 2002) e Barthes (2007), ela se acomodava nas páginas policiais dos jornais de uma imprensa que não precisa destacar seu gênero, a imprensa feita para homens. É o caso da morte de Euclides da Cunha, baleado pelo amante de sua esposa, Dilermando de Assis, em duelo pela honra, que resultou na morte do primeiro. Ana de Assis, mulher de Euclides, se torna então antítese da guardiã da família. No processo, roupas íntimas de Ana, que comprovariam adultério, foram anexadas como justificativa para a ida do escritor ao encontro de Dilermando. Há um imaginário ${ }^{8}$ constituído aí que escapa à ordem do simples relato, no qual a violência envolvendo a figura feminina não pode pertencer ao mesmo mundo que o das revistas que ensinam sobre ser mulher. E esse imaginário, no jornalismo não feminino, não deveria alcançar a vida dos lares das mulheres ensinadas ${ }^{9}$, aparecendo como um pesadelo ou algo improvável, ficcional, ainda que real, ainda que escondido ou indesejável. Às mulheres não parecia caber ou corresponder a, nas revistas femininas, histórias que não fossem do lar composto por um mantenedor masculino paterno, uma esposa feliz com os afazeres domésticos e crianças moldadas para terem o mesmo destino que seus pais, em que a paz de um mundo perfeito não permitia vislumbrar traços de qualquer agressão. Os fait divers dos componentes sombrios da realidade, por outro lado, se ausentavam das páginas dessas publicações.

Evidentemente, seu conteúdo não é estranho ao mundo: desastres, assassínios, raptos, agressões, acidentes, roubos, esquisitices, tudo isso remete ao homem, a sua história, a sua alienação, a seus fantasmas, a seus sonhos, a seus medos: uma ideologia e uma psicanálise do fait divers são possíveis; no nível da leitura, tudo é dado num fait divers; suas circunstâncias, suas causas, seu passado, seu desenlace; sem duração e sem contexto, ele constitui um ser imediato, total, que não remete, pelo menos formalmente, a nada de implícito (BARTHES, 2007, p. 58).

Desse modo, por mais de um século, fait divers que lidam com o crime (o crime misterioso, perturbador, como afirma Barthes) eram raros em páginas voltadas ao público feminino, nas quais o verdadeiro crime é não seguir a natureza verdadeira da mulher (FREIRE, 2006). Freire (2006) ainda mostra que, na construção da imagem da mulher nas revistas femininas, de responsabilidade sobre a higienização dos corpos, a alimentação dos filhos, a vigilância do crescimento, todos esses elementos foram naturalizados dentro

7 Em um panorama amplo da imprensa brasileira, o estudo Imprensa e agenda de direitos das mulheres - Uma análise das tendências da cobertura jornalística (VIVARTA, 2011) aponta que a violência contra mulheres é bastante pautada (63,3\% do universo investigado), mas a qualidade da cobertura é questionada, já que quase $74 \%$ das violências são individualizadas, apagando seu caráter institucional, sistêmico e estrutural. Outro dado relevante é que quase metade dessas notícias ocupam cadernos locais ou policiais, o que reforça a despolitização e superficialidade da cobertura.

8 Imaginário aqui não diz respeito a algo irreal, mas a imagens que habitam nossas interpretações acerca da realidade.

9 Embora alcançasse e estivesse sempre lá. 
do mundo perfeito da família de classe média burguesa, sem espaço para as perturbações da experiência humana. Nesse contexto, há forte conteúdo moralizante e pedagógico nessas publicações sobre como ser mulher nessa família burguesa.

Ao adentrar as páginas das revistas femininas, ou os conteúdos do jornalismo feminino, entretanto, é muitas vezes como forma discursiva folhetinesca que acabam se impondo, o que aproxima esse tipo de narrativa do melodramático, que atravessa não só o jornalismo, mas a cultura popular e de massa como elemento captador de atenção dos públicos e audiências, por seus constituintes emocionais e catárticos. também nesses relatos, dando continuidade ao imaginário de um feminino estranho, perturbador, ainda que assentado num intuito de dar voz a esse mesmo feminino, que não é na verdade estranho, inserindo-o no urgente debate sobre as violências de gênero. Ao mesmo tempo, na busca de 'seriedade' discursiva acerca de temas que requerem um cuidado maior, a narrativa tenta objetivar a experiência que não pode ser objetivada, de tal modo que esses conteúdos se erguem sobre estratégias confusas e transformam os relatos em algo menor (embora haja toda uma imbricada rede de sentidos sobre as vivências contadas e que se revela em fragmentos). Esses elementos podem suplantar a mulher que fala, debaixo dos horrores (MODESTO, 2016).

Campos (2013, p. 154) reforça a composição do 'jornalismo dito feminino' praticado por Marie Claire, em que o tema da violência contra a mulher divide espaço com moda, beleza, entre outros, ressaltando a prevalência da violência doméstica entre os assuntos abordados. "Devemos nos perguntar se a revista divulga a violência de gênero porque 'está na moda', ou com a finalidade de promover transformações no contexto social”, indaga a autora. Para ela, as reportagens sobre violências de gênero na revista são contrastantes com os demais temas abordados, ao restabelecer uma conexão com o mundo exterior e descolar-se da dimensão do consumo. "Dessa forma, identifica-se nas reportagens, um jornalismo de cunho informativo, o qual favorece a conexão da mulher com o mundo externo e revela a situação desta num contexto social, onde a violência de gênero não a toma como consumidora, mas como parte integrante de um problema social." Um levantamento quantitativo resultante da busca pela palavra 'estupro' no site da revista resultou na identificação, por nós, de 27 relatos testemunhais sobre o tema em Marie Claire, distribuídos conforme a Tabela 1. Os dados condensam a primeira aproximação do universo, para compreendê-lo, dimensioná-lo e, então, selecionar o corpus da análise.

\section{Tabela 1 - Relatos testemunhais sobre estupro identificados em Marie Claire}

\begin{tabular}{cc} 
Ano & Quantidade de testemunhos \\
\hline 2005 & 1 \\
2014 & 2 \\
2016 & $13^{*}$ \\
2017 & 3 \\
2018 & 2 \\
2019 & 6 \\
\hline
\end{tabular}

Fonte: elaboração das autoras.

Nota: o * indica que não necessariamente são todos de 2016, conforme será visto a seguir.

Algumas observações devem ser feitas sobre os dados obtidos: é possível que os resultados não deem conta de todos os relatos da revista acerca do tema, por conta de possíveis falhas na digitalização de edições antigas, de deficiências dos mecanismos de busca ou de relatos testemunhais sobre o tema que, 
eventualmente, não mencionem a palavra estupro ${ }^{10}$. Um texto de 2019 é um metarrelato focado em um livro e, por isso, não é analisado. Importante destacar também que, em 2016, o ano com mais publicações, durante a mobilização já citada alguns relatos de anos anteriores foram recuperados e republicados no contexto da discussão da cultura do estupro (nome da retranca utilizada pela revista para abrigar os relatos), o que não permite afirmar que todos eles sejam de 2016. Como, naquele ano, os relatos testemunhais não foram abrigados sob a retranca 'Eu, leitora', não os discutimos aqui, mas consideramos importante enumerá-los, até porque ajudam a dar conta de certa tendência do jornalismo de modo geral, presente em Marie Claire: a de aumentar a frequência com que aborda o tema estupro à medida que o assunto ganha a esfera pública $\mathrm{e}$ que acontecimentos e movimentos como o \#metoo ${ }^{11}$ repercutem no país e no exterior. Essa evidência ganha corpo ao acompanharmos, no Brasil, denúncias como as feitas contra o médium João de Deus, em 2018, e a atualização dos testemunhos contra o ex-médico Roger Abdelmassih, dados originalmente a partir de 2009, mas recuperados recentemente em série documental e ficcional (Assédio), exibida também em 2018. A partir dessas considerações, nossa análise recai sobre 13 testemunhos, conforme o Quadro 1.

\section{Quadro 1 - Testemunhos de 'Eu, leitora' analisados}

\begin{tabular}{|l|l|}
\hline Ano & Título \\
\hline 2005 & "Como superei um estupro" \\
\hline 2014 & Depoimento: "Meu professor arrancou minha virgindade", diz Aurora, 35 anos, terapeuta* \\
\hline 2014 & Depoimento: "Fui estuprada pelo meu melhor amigo", diz Rafaela, 23 anos, arquiteta* \\
\hline 2017 & "Fui estuprada nas férias e usei minha dor para ajudar outras mulheres" \\
\hline 2017 & "Fui estuprada por um homem que se passava por policial" \\
\hline 2017 & "Fiz um aborto depois de ser dopada e estuprada" \\
\hline 2018 & "Sofri estupros e abusos e hoje ajudo vítimas do mundo todo" \\
\hline 2018 & "Fui molestada na infância, vivi um relacionamento abusivo e me curei com plantas e aromas naturais" \\
\hline 2019 & "Sofri quatro abusos sexuais do líder espiritual Gê Marques, em quem confiava plenamente" \\
\hline 2019 & "Fui estuprada, esfaqueada, me prostituí e aprendi a ler o ser humano", diz Luísa Marilac \\
\hline 2019 & "Fui estuprada durante quatro horas, dentro de um carro em movimento" \\
\hline 2019 & "Fui estuprada, me negaram um aborto e quis me matar" \\
\hline 2019 & Jovem estuprada por motorista da Uber escreve desabafo: "Nem sei por quanto tempo chorei" \\
\hline
\end{tabular}

Fonte: elaboração das autoras.

De acordo com Márcio Seligmann-Silva (2010, p. 5), o paradigma testemunhal que ganha força no século XX, da/o sobrevivente, de "alguém que habita na clausura de um acontecimento extremo que o aproximou

10 Filtramos a busca apenas pela palavra 'estupro' para diferenciá-lo de outras violências sexuais, inspiradas pelos apontamentos de Virginie Despentes (2018, p. 32, grifo original): “enquanto não é nomeada, a agressão perde sua especificidade [...] a partir do momento que se chama estupro de estupro, todo o aparelho de vigilância feminino se coloca em andamento [...] Você quer que todo mundo veja como uma mulher que foi vítima 'disso'?”. O medo do estigma cria, diz a autora, um silêncio cruzado, asfixiante para a mulher, que não pode contar a ninguém o que lhe ocorreu. Portanto, nomear, falar 'estupro', é uma forma de retirar o termo de seu silêncio, conferir-lhe especificidade e espessura e, também, de retirar as mulheres desse lugar de silenciamento patriarcalmente imposto.

11 O \#metoo foi criado, em 2006, pela ativista estadunidense Tarana Burke. O objetivo era auxiliar mulheres que viveram experiências de violência de gênero a compartilhar seus traumas. Quando as denúncias contra o produtor de cinema Harvey Weinstein surgiram, em 2017, o nome foi catapultado como hashtag no Twitter e depois em outras redes, por atrizes e profissionais do setor, para marcar relatos testemunhais de abusos cometidos por ele e outros nomes da indústria audiovisual. Por meio da hashtag \#metoo, as mulheres compartilham experiências de assédio e violência sexual. 
da morte", diz respeito a uma aporia do testemunho, de ser, ao mesmo tempo, exemplar e singular, ao negar a universalidade da linguagem - e de manter sua força na superstes, na incapacidade de narração diante de sua premência narrativa para o sujeito que experienciou esse limite. Isso tudo, nos lembra o autor, não exclui a tradição jurídica do testemunho como téstis ${ }^{12}$ - que se aproxima do dito gênero depoimento que estaria presente em Marie Claire; ao contrário, para Seligmann-Silva (2010, p. 5), o testemunho deve ser compreendido "na sua complexidade enquanto misto entre visão, oralidade narrativa e capacidade de julgar: um elemento complementa o outro, mas eles relacionam-se também de modo conflituoso".

Nesse sentido, o teor testemunhal é constituído de cacos; de lacunas de uma experiência profundamente singular daquele sujeito; ainda que tantos sujeitos compartilhem dessa experiência traumática ${ }^{13}$. "Neste testemunho, misturam-se fragmentos, como que estilhaços (metonímias) do seu passado traumático, a uma narrativa instável e normalmente imprecisa, mas que permite criar o referido 'volume' e, portanto, um novo local fértil para a vida" (SELIGMANN-SILVA, 2010, p. 11). Esse caráter narrativo fragmentário e lacunar parece estar em constante tensão com a pretensão do jornalismo de dar sentido ao mundo, ou, nas palavras de Gislene Silva (2005), como "entendimento de mundo" (p. 96), muitas vezes produzindo uma unidade artificial e simplificando eventos e processos complexos. Nos relatos testemunhais de 'Eu, leitora' sob visada aqui, percebe-se a busca da normalização do discurso das mulheres. Isso ocorre a partir da elaboração de uma narrativa linear, em que as temporalidades de passado e presente parecem estar muito mais conciliadas no relato do sujeito traumatizado que em outras narrativas de teor testemunhal que não se identificam como jornalísticas, como aquelas captadas e narradas por Svetlana Alexiévitch ${ }^{14}$.

Esse ordenamento temporal vem, em muitos testemunhos, acompanhado de certo apagamento de lapsos, de episódios soterrados, de silêncios. $\mathrm{O}$ acontecimento jornalístico é narrado de maneira ordenada - a compreensão do tempo se dá como uma flecha que segue, linear, do passado em direção ao futuro. Essa estrutura fica clara no relato 'Fui estuprada durante quatro horas, dentro de um carro em movimento', de Andrezza Nascimento, por meio de dêiticos como 'quando', 'durante', 'nesse momento' 'aú', 'depois', que estabelecem a sequência de eventos no tempo. $O$ texto também permite a demarcação temporal típica da precisão jornalística por meio de expressões como 'há algumas semanas', 'quatro horas depois', 'durante 30 minutos'. Algo entre similar e distinto ocorre no relato de Palmira Margarida, 'Fui molestada na infância, vivi um relacionamento abusivo e me curei com plantas e aromas naturais', em que a narrativa inicia na infância e segue até os dias de hoje. O estupro, porém, surge como um flashback, uma memória reprimida que voltou à superfície, primeiro como crises de pânico, depois como lembrança. Ainda assim, esse é o único instante de ruptura na linearidade temporal do relato.

Todavia, algumas mulheres revelam, nos textos, não se lembrar de diversos momentos dos estupros muitas vezes, porque foram dopadas: "Lembro dele me entregando a garrafa aberta. Tomei uns dois goles. A partir daí, minha memória vem em flashes. Não me lembro de descer do carro, atravessar a portaria e entrar na casa da minha mãe" (LAZZERI, 2019), narra Larissa (nome fictício dado pela revista) no texto 'Jovem estuprada por motorista da Uber escreve desabafo: 'Nem sei por quanto tempo chorei”. "À frente, continua: Cada flash de memória era uma nova tormenta. No primeiro, lembro do motorista da Uber vindo para o banco de trás. Depois, dele puxando minha calça - e, de fato, a calça estava rasgada. A calcinha, suja.

12 Cabe ressaltar que o testemunho jurídico também se constrói como um locus narrativo em que a testemunha se responsabiliza por dizer a verdade e, ainda assim, permanece sob dúvida.

13 No caso dos testemunhos que moldam essa visão, trata-se de eventos traumáticos coletivos, como a Shoah, o genocídio armênio, o genocídio ruandês dos tutsis. A violência do estupro é profundamente privada, por ocorrer, em sua singularidade, a uma vítima, a um corpo, infligido por um ou mais perpetradores. Ao mesmo tempo, não podemos descolá-la de sua natureza estrutural e, portanto, pública e exemplar. No estupro, a exemplaridade é demarcada ainda porque a experiência de ser mulher, no patriarcado, é moldada a partir da ameaça constante de violação, como dissemos.

14 Não à toa, a escritora bielorrussa rejeita em entrevistas a designação de jornalismo para o trabalho que realiza, talvez para escapar dessa tensão. 
Fui para a casa da minha amiga na noite anterior usando um absorvente interno, estava no fim do ciclo menstrual. Voltei sem" (LAZZERI, 2019).

No texto, Larissa conta que o delegado que a atendeu ressaltou o caráter lacunar da memória traumática ou, nas palavras de Pollak, "lembranças traumatizantes" (1989, p. 5).

No relato 'Fiz um aborto depois de ser dopada e estuprada', de Mirella Floren, a lacuna mnemônica também é provocada, parcialmente, pela dopagem: "Em no máximo 30 minutos eu comecei a ficar muito cansada e com sono. Achei estranho, pois já tinha perdido a conta de quantas vezes voltara bêbada da balada às seis da manhã. Eu apaguei no sofá. Minha única lembrança do momento vem em um flash, com Pietro em cima de mim" (SENNA, 2017). Porém, a mulher conta que decidiu apagar o episódio e que somente anos depois a lembrança traumática emergiu: "Um dia, aos 26 anos, a chavinha virou. Não sei o motivo, mas foi só aí que entendi, de fato, que havia sido estuprada. Comecei a contar para as pessoas e, assim, consegui resgatar alguns detalhes do dia” (SENNA, 2017). Ou seja, em alguns relatos há um imbricamento entre a memória lacunar de origem fisiológica e cientificamente explicável (pelo doping) e as lacunas da memória traumática, com ênfase na primeira, que tem causa rastreável, lógica, e que é, portanto, legitimada pelo jornalismo. O efeito produzido por essas estratégias narrativas é de textos eventualmente mais próximos do depoimento jurídico-positivista e da téstis, que coloca a oralidade narrativa do testemunho traumático em segundo plano.

Outras pequenas marcas discursivas são detectáveis nos testemunhos, criando uma confusão entre primeira e terceira pessoas, e provocando instabilidade no eu-narrador(a). No testemunho 'Fiz um aborto depois de ser dopada e estuprada', um dedo-duro (em itálico) ao fim do texto anota "Nome trocado a pedido da entrevistada" (SENNA, 2017) (paratexto comum a diversos relatos), mas o texto em momento algum anuncia que houve uma entrevista nem quem seria o/a entrevistador/a, e a declaração de autoria traz 'Cristiane Senna', provavelmente a jornalista que captou o testemunho - vários testemunhos têm assinatura presumida da jornalista (um é assinado por um homem); o testemunho 'Como superei um estupro' explicita a mediação da jornalista: "Depoimento a Fernanda Dannemann" (2005). O relato 'Jovem estuprada por motorista da Uber escreve desabafo: 'Nem sei por quanto tempo chorei" traz, no final, novamente em itálico, um aviso de que a reportagem entrou em contato com a empresa citada e a resposta da Uber. A instabilidade do eu-narrador(a) é demarcada ainda, na revista, pelo uso de sutiãs em terceira pessoa que, abaixo do título, resumem o relato, como em 'Eu, Leitora: 'Sofri quatro abusos sexuais do líder espiritual Gê Marques, em quem confiava plenamente": "Com uma fé inabalável, Patrícia [nome fictício para preservar a identidade da vítima], hoje com 44 anos, acreditava no discurso de seu líder espiritual, mas alega que foi surpreendida por um homem violento que a estuprou [...]" (CARVALHO, 2019).

A terceira pessoa coloca em cena um outro que não a sobrevivente que testemunha, mas a figura do/a jornalista que opera também como testemunha ao escutar a dor do/a outro/a e carregá-la adiante, contra o negacionismo do esquecimento e do soterramento (SELIGMANN-SILVA, 2008). Além disso, o colchete que revela o anonimato também desestabiliza o relato testemunhal, bem como a expressão 'alega que', típica do jornalismo convencional de depoimentos e confrontação de versões, em que a verdade do sujeito precisa ser cotejada com outras fontes em busca da dita objetividade ou do objetivismo, a que já aludimos anteriormente (GOMES BARBOSA; VARÃO, 2018). Ainda que a grande maioria dos títulos expresse a voz da mulher que testemunha, a narradora, o 'eu' de 'Eu, leitora', em algumas edições, até mesmo no título, a voz testemunhal é desestabilizada, como no título 'Jovem estuprada por motorista da Uber escreve desabafo: 'Nem sei por quanto tempo chorei” ou em 'Depoimento: 'Meu professor arrancou minha virgindade', diz Aurora, 35 anos, terapeuta'.

Os relatos de Marie Claire trazem mulheres submetidas a uma violência estrutural e sistêmica no país. Os testemunhos explicitam ainda o entorno de um estupro: trata-se de um evento traumático que se desdobra 
no tempo, nas relações das mulheres violentadas e, muitas vezes, desencadeia uma série de outras violências. Algumas das autoras dos testemunhos contam que foram estupradas e depois viveram relacionamentos abusivos; algumas sofreram vários estupros ao longo da vida, desde crianças, ou outros abusos simbólicos, afetivos e materiais, explicitando condições de vulnerabilidade patogênica' ${ }^{15}$ (MACKENZIE; ROGERS; DODDS, 2014) a que estão submetidos sujeitos como mulheres trans (caso do relato testemunhal de Luísa Marilac, 'Fui estuprada, esfaqueada, me prostituí e aprendi a ler o ser humano'). Após o estupro, algumas mulheres foram culpabilizadas por família, amigos ou parceiros por um suposto comportamento que teria incitado o crime; outras foram desacreditadas pelo aparato policial ou tratadas de maneira distinta do que preconizam especialistas da área - dois elementos da cultura do estupro. Muitos relatos testemunhais emendam à violência sexual episódios de abortos, que por sua vez envolvem violências como a negação médica do acesso ao aborto legal ou, novamente, a reprovação social do entorno familiar pelo ato oriundo de um estupro. O mergulho nesses textos nos leva a ver uma rede de traumas, que conectam rupturas de integridade e violações de direitos humanos (SAFFIOTI, 2004) sistemática e estruturalmente sofridas pelas mulheres, nem sempre ocasionadas pelo estupro, como o aborto, mas envolvidas na cultura patriarcal que expropria as mulheres da posse e humanidade de seus corpos expondo-os a violações diversas.

\section{UMA QUESTÃO DE LUGAR}

Como dissemos, por décadas o jornalismo dito feminino buscou afastar de suas páginas a violência contra a mulher, tido como um assunto não feminino - não pertencente ao domínio da feminilidade e que não dizia respeito às mulheres, apesar de atingi-las diretamente. O tema aporta nas páginas de 'Eu, leitora' em meados dos anos 2000, este locus hibridizado em que a leitora comum tem protagonismo ao narrar suas experiências de vida, a maioria delas em proximidade com o fait divers. Ao alocar esses relatos de estupro ao lado de narrativas de teor testemunhal engraçadas, dramáticas, enternecedoras, Marie Claire opera uma equalização de experiências de vida que não são de maneira alguma equalizáveis: como se narrar a experiência de um trauma, uma experiência-limite que faz o sujeito atravessar a fronteira da linguagem e retornar, sem palavras, à superfície, fosse algo da ordem do coloquial.

Mais: ao elencar a violência sexual como um tema possível dentro de um rol de narrativas que se aproximam do fait divers, Marie Claire parece efetuar o duplo gesto de retirar o peso violento do estupro na vida das mulheres, visto que seria algo da ordem do curioso, do interessante, da vida, do ordinário. Ao fazer isso, simultaneamente confirma, sem muito disputar, o caráter 'fundador' do estupro nas subjetividades femininas, como defende Virginie Despentes (2018, p. 33), "trauma crucial, fundamental, definição primeira de feminilidade”. É importante destacar que uma mulher estuprada não precisa, se não desejar / se conseguir, ocupar apenas o lugar de sobrevivente. Mas isso não faz o estupro desaparecer. Nas palavras de Despentes (2018, p. 31): "o estupro é algo que pegamos e do qual não nos desvencilhamos nunca. Contaminadas"; e, de fato, no contexto do heteropatriarcado, é algo que as mulheres podem esperar ao correrem o risco de se aventurar. Mais à frente, ela acrescenta: trata-se de viver com, sem negar ou sucumbir (2018, p. 36) ${ }^{16}$.

Porém, a posição da revista é ambígua porque, ainda assim, dá nome a algo que, por muito tempo, permaneceu inaudito, silenciado. Despentes (2018) narra que ao longo dos séculos tem-se dado outro

15 De acordo com Catriona Mackenzie, Wendy Rogers e Susan Dodds (2014, p. 9), a vulnerabilidade patogênica tem fontes variadas, que incluem relações interpessoais e sociais abusivas ou moralmente disfuncionais, além de opressões sociais e injustiças - descrições bastante precisas para as opressões estruturais de gênero, sexualidade, raça (e outras) no heteropatriarcado.

16 A esse respeito, Roxane Gay afirma que é marcada indelevelmente pela violação que sofreu, o que a torna uma sobrevivente - mas não só. “Ao longo dos anos, aprendi a importância da sobrevivência e de reivindicar o rótulo de 'sobrevivente', mas não me importo com o rótulo de 'vítima'. Também não vejo vergonha alguma em dizer que, após ter sido estuprada, eu me tornei uma vítima, e até hoje, embora seja muitas outras coisas, ainda sou uma vítima” (GAY, 2017, p. 25). 
nome à coisa, enfeitando a violência. Mas as pressões dos movimentos feministas e os relatos das mulheres finalmente trazidos à tona permitem a fala em voz alta do estupro. As falas performáticas 'eu fui estuprada', ao lado de 'ele estuprou' e de 'foi um estupro' permitem que a violência sexual seja levada à existência saindo das sombras de sua ocultação pelo patriarcado; que seja nomeada, discutida, acusada, julgada, debatida na esfera pública; que deixe, enfim, de ser "uma guerra que se trava no silêncio e na obscuridade" (DESPENTES, 2018, p. 31). E, nesse contexto, 'Eu, leitora' tem papel fundamental ao deslocar o jornalismo dito feminino de uma aderência à feminilidade hegemônica, aproximando-o das experiências de tantas mulheres: um estupro a cada 8 minutos, não nos esqueçamos.

A afirmação testemunhal e pessoal de cada mulher estuprada, nas páginas do 'Eu, leitora' de Marie Claire, também é carregada de ambiguidade no que diz respeito à verdade, parecendo opor, ou ao menos não conciliar, a verdade jornalística e a verdade testemunhal. De um lado, a revista acredita nessas mulheres, ao dar-lhes espaço e amplificar suas vozes nas narrativas traumáticas, uma palavra que tem sido historicamente desacreditada, silenciada e colocada em xeque. A palavra da mulher que acusa um homem de estupro passa, aos poucos, a deixar de ser duvidosa, quando o jornalismo publica essa verdade testemunhal em suas páginas. Conforme Dias (2013, p. 106), "por meio dessas histórias contadas e muitas vezes 'enfeitadas', é enunciada uma experiência, onde ecoam vozes sociais, e muitas vezes, a única forma que muitas mulheres encontram para ter contato com o tema, e assim, desencadear a vontade de falar, e atribuir um sentido às feridas."

Mas a credibilidade adquirida pela palavra da mulher que testemunha o estupro que sofreu é precária; isso se deve à posição de 'Eu, leitora' na estrutura editorial de Marie Claire como revista. A seção, apartada da verdade jornalística obtida por meio dos procedimentos do jornalismo industrial e de princípios editoriais como os elencados pelo Grupo Globo - isenção, correção e agilidade -, busca se apresentar como uma verdade pela qual a revista não se responsabiliza; e que, portanto, não lhe diz respeito, ainda que o espaço aberto para esses testemunhos represente a crença na verdade desses relatos e dessas mulheres, a partir do que diz Gagnebin (2006). São verdades daquelas mulheres, não necessariamente sancionadas por Marie Claire, ainda que veiculadas e carregadas por ela - uma posição ambígua, de afirmação e fraqueza. O Grupo Globo, nos mesmos princípios editoriais (2011), discute o conceito de verdade, afirmando que, por mais inesgotável que seja, ela existe. Situa, porém, a discussão na tradição patriarcal do jornalismo que opõe objetividade e verdade ao que chama de 'subjetivismo' e, em busca de 'contornar essa simplificação em torno da "verdade", define o jornalismo a como produção de conhecimento e a partir da ideia de verdade dos fatos, no modelo hegemônico que abordamos - claramente insuficiente para abarcar a instável verdade testemunhal. O feminist standpoint há muito defende a ideia de que os saberes são situados ou localizados, logo "requerem que o objeto do conhecimento seja visto como um ator e agente, não como uma tela [...] nunca como um escravo do senhor que encerra a dialética apenas na sua agência e em sua autoridade de conhecimento 'objetivo"' (HARAWAY, 1995, p. 36) - objetividade, aqui, como a junção de visões parciais e vozes vacilantes. Trata-se, diz Donna Haraway, "de viver dentro de limites e contradições, isto é, visões desde algum lugar" (HARAWAY, 1995, p. 33-34).

Assim, há um confronto entre as exigências do jornalismo hegemônico, calcado em fundamentos patriarcais, de um lado, e as demandas de crença na verdade do outro postas pelo testemunho, bem como a perspectiva feminista que percebe a impossibilidade de uma objetividade externa, de outro. A solução certamente não é fácil, e passa pelo tensionamento da compreensão de verdade e objetividade que rege o jornalismo, abrindo espaço para aceitar como verdadeiras experiências narradas por sujeitos tradicionalmente excluídos da narração pública e, portanto, sem credibilidade - entre os quais mulheres. É necessário, então, um gendramento do jornalismo, um jornalismo feminista: fundado na perspectiva, em uma nova compreensão da objetividade e a favor das mulheres (GOMES BARBOSA; VARÃO, 2018). 
A despeito dessa posição editorial mais ampla do conglomerado midiático, a própria intervenção e imiscuição de autoria elaboradas pela revista em alguns testemunhos, demarcadas por estratégias jornalísticas como a designação da/o repórter que o captou, o título em terceira pessoa, os sutiãs explicativos, os dedos-duros e os esclarecimentos editoriais, impedem que esse distanciamento se complete, conectando a verdade testemunhal singular de cada mulher à verdade jornalística de Marie Claire. Uma verdade multifacetada ou, conforme Gomes Barbosa, Varão e Carvalho (2019), um testemunho mediado; ao mesmo tempo que aproximada de narrativas de experiências não-traumáticas das mulheres, uma verdade articulada por/em um jornalismo que se afasta da feminilidade hegemônica e ganha relevância ao dar espaço para testemunhos de algo silenciado por séculos. Assim, podemos pensar que Marie Claire contribui, mesmo que de maneira não isenta de problematizações, para a restauração de cada subjetividade ferida e cindida das mulheres marcadas pelo trauma do estupro, ao permitir e materializar a existência dos testemunhos em suas páginas. Para além do âmbito subjetivo (sem negar a importância capital deste, como as narrativas testemunhais de Despentes, Gay e tantas outras mulheres atestam), Marie Claire também contribui para o enfrentamento da cultura do estupro e para a meta (utópica?) de sua superação, ao dar nome, detalhes e nuances a essas experiências de vulnerabilização patogênica que as mulheres vivem no Brasil por meio da violação de seus corpos. Trata-se do exercício de um jornalismo gendrado, ou seja, com perspectiva de gênero, a favor das mulheres, apesar de tudo.

\section{REFERÊNCIAS}

ANTUNES, Elton. Acontecimento, temporalidade e a construção do sentido de atualidade no discurso jornalístico. Contemporânea, Salvador, v.5, n. 1, p. 1-21, 2008. Disponível em: https://periodicos.ufba.br/index. php/contemporaneaposcom/article/view/3517. Acesso em: 23 jul. 2021.

BARTHES, Roland. Crítica e verdade. São Paulo: Perspectiva, 2007.

BUENO, Samira; SOBRAL, Isabela. Um estupro a cada 8 minutos. In: BUENO, Samira; LIMA, Renato Sérgio de (org.). Anuário Brasileiro de Segurança Pública 2020. São Paulo: Fórum Brasileiro de Segurança Pública, 2020. p. 132-138. Disponível em: https://forumseguranca.org.br/wp-content/uploads/2020/10/anuario14-2020-v1-interativo.pdf. Acesso em: 12 jan. 2021.

BUITONI, Dulcília Schroeder. Mulher de papel: a representação da mulher pela imprensa feminina brasileira. 2. ed. São Paulo: Summus, 2009.

BUSTAMANTE, Luisa. Depois daquele estupro coletivo: o que aconteceu com os acusados? Agência Lupa, Rio de Janeiro, 8 mar. 2017. Disponível em: https://piaui.folha.uol.com.br/lupa/2017/03/08/violencia-contra-amulher-21. Acesso em: 20 jan. 2021.

CAMPOS, Danieli Aparecida. Pra que rimar amor e dor?: análise das representações da violência de gênero na revista Marie Claire (2002-2011). 2013. 187 f. Dissertação (Mestrado em Comunicação). - Universidade Paulista, São Paulo, 2013. Disponível em: https://repositorio.unip.br/wp-content/uploads/2020/04/comunic danieliaparecidacampos.pdf. Acesso em: 21 jan. 2021.

CARVALHO, Felipe. Eu, Leitora: "Sofri quatro abusos sexuais do líder espiritual Gê Marques, em quem confiava plenamente". Marie Claire, São Paulo, p. 1-1, 21 jan. 2019.

DANNEMANN, Fernanda. "Como superei um estupro". Marie Claire, São Paulo, p. 1-1, jun. 2005.

DAS, Veena. Vida e palavras: a violência e sua descida ao ordinário. São Paulo: Unifesp, 2020.

DESPENTES, Virginie. Teoria King Kong. São Paulo: N-1 edições, 2018.

DIAS, Suelly Maria Maux. Imprensa feminina, folhetim e histórias de vida. In: CONGRESSO BRASILEIRO DE CIÊNCIAS DA COMUNICAÇÃO, 26., 2003, Belo Horizonte. Anais [...]. São Paulo: Intercom, 2003. p. 1-12. Disponível em: http://www.portcom.intercom.org.br/pdfs/82582712958835071037170038566568615252.pdf. Acesso em: 12 jan. 2021. 
DUARTE, Constância Lima. Imprensa feminina e feminista no Brasil: século XIX. Belo Horizonte: Autêntica, 2018.

FREIRE, Maria Martha de Luna. Mulheres, mães e médicos: discurso maternalista em revistas femininas (Rio de Janeiro e São Paulo, década de 1920). 2006. 336 f. Tese (Doutorado em História das Ciências e da Saúde). - Fundação Oswaldo Cruz, Rio de Janeiro, 2006. Disponível em: https://www.arca.fiocruz.br/handle/ icict/19793. Acesso em: 26 jul. 2021.

GAGNEBIN, Jeanne Marie. Lembrar escrever esquecer. São Paulo: Ed. 34, 2006.

GAY, Roxane. Fome: uma autobiografia do (meu) corpo. São Paulo: Globo, 2017.

GAY, Roxane (ed.). Not that bad: dispatches from rape culture. Nova lorque: Harper Perennial, 2018.

GOMES BARBOSA, Karina. Lei e Ordem: Unidade de Vítimas Especiais e regimes de visibilidade acerca do estupro na cultura pop. Tropos: Comunicação, Sociedade e Cultura, Rio Branco, v. 9, n. 2, p. 1-23, 2020. Disponível em: https://periodicos.ufac.br/index.php/tropos/article/view/3966. Acesso em: 28 jul. 2021.

GOMES BARBOSA, Karina; VARÃO, Rafiza. Erro, dúvida e jornalismo generificado: Um olhar sobre a cobertura de estupro a partir da reportagem "A rape on campus". Brazilian Journalism Research, Brasília, DF, v. 14, n. 1, p. 12-29, 2018. Disponível em: https://bjr.sbpjor.org.br/bjr/article/view/1049/pdf 1. Acesso em: 28 jul. 2021.

GOMES BARBOSA, Karina; VARÃO, Rafiza; CARVALHO, André Luís. Os caminhos das Ariadnes: testemunho, verdade e jornalismo no enfrentamento de violências de gênero. In: BELISÁRIO, Kátia; MOURA, Dione O.; GUAZINA, Liziane (Org.). Gênero em pauta: desconstruindo violências, construindo novos caminhos. Curitiba: Appris, 2019. p. 111-119.

GROTH, Otto. O poder cultural desconhecido: fundamentos da ciência dos jornais. Petrópolis: Vozes, 2011.

GRUPO GLOBO. Princípios editoriais do Grupo Globo. Rio de Janeiro: Grupo Globo, 2011. Disponível em: https://oglobo.globo.com/principios-editoriais/. Acesso em 11 jan. 2021.

HARAWAY, Donna. Saberes localizados: a questão da ciência para o feminismo e o privilégio da perspectiva parcial. Cadernos Pagu, Campinas, n. 5, p. 7-41, 1995. Disponível em: https://periodicos.sbu.unicamp.br/ojs/ index.php/cadpagu/article/view/1773. Acesso em: 26 jul. 2021.

INSTITUTO PATRÍCIA GALVÃO. Dossiê Violência contra as Mulheres. São Paulo: Instituto Patrícia Galvão, 2015. Disponível em: https://dossies.agenciapatriciagalvao.org.br/violencia-sexual/tipos-de-violencia/estupro/. Acesso em: 10 jan. 2021.

LAZZERI, Thaís. Jovem estuprada por motorista da Uber escreve desabafo: "Nem sei por quanto tempo chorei”. Marie Claire, São Paulo, p. 1, 24 set. 2019.

MACKENZIE, Catriona; ROGERS, Wendy; DODDS, Susan. Introduction: what is vulnerability, and why does it matter for moral theory? In: MACKENZIE, Catriona; ROGERS, Wendy; DODDS, Susan. Vulnerability: new essays in ethics and feminist philosophy. Nova York: Oxford University Press, 2014. p. 1-29.

MARIE CLAIRE. Perfil do leitor. Rio de Janeiro, Editora Globo, 2020. Disponível em: https://www. publicidadeeditoraglobo.com.br/marieclaire. Acesso em: 20 jan. 2021.

MÍDIA DADOS BRASIL 2020: para todxs. São Paulo: Grupo de Mídia São Paulo, 2020. Disponível em: $\underline{\text { https:// }}$ midiadados2020.com.brl. Acesso em: 21 jun. 2021.

MODESTO, Celina Alice Carvalho. Mulheres "sensacionais": uma análise da construção da mulher no Jornal Já. 2016. 160 f. Dissertação (Mestrado em Jornalismo) - Universidade Federal da Paraíba, João Pessoa, 2016.

MOTTA, Luiz Gonzaga. Análise crítica da narrativa. Brasília, DF: Editora UnB, 2013.

POLLAK, Michael. Memória, esquecimento, silêncio. Estudos Históricos, Rio de Janeiro, v. 2, n. 3, p. 3-15, 1989. Disponível em: http://www.uel.br/cch/cdph/arqtxt/Memoria esquecimento silencio.pdf. Acesso em: 20 jun. 2021. 
QUEIROZ, Rosane. O melhor do Eu, leitora: depoimentos reais publicados por Marie Claire. São Paulo: Globo, 2008.

REDAÇÃO MARIE CLAIRE. 33 estupros, um relato por dia: leitoras contam suas histórias. Marie Claire, Rio de Janeiro, 3 jun. 2016. Notícias. Disponível em: https://revistamarieclaire.globo.com/Noticias/ noticia/2016/06/33-estupros-um-relato-por-dia-leitoras-contam-suas-historias.html. Acesso em: 10 jan. 2021.

SAFFIOTI, Heleieth. Gênero, patriarcado, violência. São Paulo: Fundação Perseu Abramo, 2004.

SEGATO, Rita Laura. Território, soberania e crimes de segundo Estado: a escritura nos corpos das mulheres de Ciudad Juarez. Revista Estudos Feministas, Florianópolis, v. 13, n. 2, p. 265-285, jan. 2005. Disponível em: https://periodicos.ufsc.br/index.php/ref/article/view/S0104-026X200500020004/7818. Acesso em: 10 jan. 2021.

SELIGMANN-SILVA, Márcio. Narrar o trauma - a questão dos testemunhos de catástrofes históricas. Psicologia Clínica, Rio de Janeiro, v. 15, n. 2, p. 65-81, 2008. Disponível em: https://www.scielo.br/j/pcl a/5SBM8yKJG5TxK56Zv7FgDXS/abstract/?lang=pt. Acesso em: 23 jul. 2021.

SELIGMANN-SILVA, Márcio. O local do testemunho. Revista Tempo e Argumento, Florianópolis, v. 2, n. 1, p. 3-20, 2010. Disponível em: https://www.revistas.udesc.br/index.php/tempo/article/view/1894. Acesso em: 12 jan. 2021.

SENNA, Cristiane. Eu, leitora: "Fiz um aborto depois de ser dopada e estuprada". Marie Claire, São Paulo, p. 1-1, 21 nov. 2017.

SERINO, Mônica. Apresentação. In: QUEIROZ, Rosane. O melhor do Eu, leitora: depoimentos reais publicados por Marie Claire. São Paulo: Globo, 2008. p. 6-7.

SILVA, Gislene. Jornalismo e construção de sentido: pequeno inventário. Estudos em Jornalismo e Mídia, Florianópolis, v. 2, n. 2, p. 95-107, 1 jan. 2005. Disponível em: https://periodicos.ufsc.br/index.php/jornalismo/ article/view/2145. Acesso em: 20 jan. 2021.

VERGĖS, Françoise. Um feminismo decolonial. São Paulo: Ubu Editora, 2020.

VIEGAS, Rafael Marcelo. Cristeman, o Terrível: um fait divers do século XVI. Alea : Estudos Neolatinos, Rio de Janeiro, v. 16, n. 2, p. 362-385, 2014. Disponível em: https://doi.org/10.1590/S1517106X2014000200008. Acesso em: 26 jul. 2021.

VIVARTA, Veet (org). Imprensa e agenda de direitos das mulheres: uma análise das tendências da cobertura jornalística. Brasília, DF: Andi: Instituto Patrícia Galvão, 2011.

WOLF, Mauro. Teorias da Comunicação. Lisboa: Editorial Presença, 2002. 